\title{
A hősokkfehérjék hatása a máj ischaemiás-reperfúziós károsodására
}

\author{
Rostás Andrea dr. ${ }^{1,4}$ - Sabry Ahmed dr. ${ }^{3}$ - Ghosh Subhamay dr. ${ }^{1,2}$ \\ ${ }^{1}$ Anaesthetics and Pain Management, Glangwili General Hospital, Hywel Dda University Health Board, \\ Carmarthen, U.K. \\ ${ }_{2}^{2}$ Pécsi Tudományegyetem, Általános Orvostudományi Kar, Aneszteziológiai és Intenzív Terápiás Intézet, Pécs \\ ${ }^{3}$ Department of Anaesthetics, Walsall Healthcare NHS Trust, U.K. \\ ${ }^{4}$ Szegedi Tudományegyetem, Általános Orvostudományi Kar, Sebészeti Műtéttani Intézet, Szeged
}

\begin{abstract}
A májbetegségekkel és májműtétekkel kapcsolatos morbiditás és mortalitás fó oka a beáramlási akadály következtében kialakult ischaemiás-reperfúziós károsodás. A stresszfehérjék családjába tartozó hősokkfehérjék a sejthomeosztázis fenntartása és az immunrendszer szabályozása mellett a máj regenerálódásában is bizonyítottan fontos szerepet játszanak. Humán szervezetben az ischaemiás-reperfúziós károsodás alapvető indikátorai, valamint a máj múködésére és regenerációjára is hatással vannak. A dolgozat elsődleges célja a hősokkfehérjék potenciális szerepének ismertetése diagnosztikus markerként májbetegségekben, valamint terápiás célpontként kritikus állapotokban. Először a hősokkfehérjék endogén rendszerként való alapvető szerepére koncentrál, ugyanis ez összefüggést mutat a májkárosodással. Ez megmagyarázza a hősokkfehérje-70 hatását a máj megbetegedéseire és az ischaemia-reperfúzióra. Ezt követően vizsgálja a hôsokkfehérjék lehetséges diagnosztikus szerepét, végül potenciális terápiás eszközként való használatát tekinti át. Orv. Hetil., 2016, 157(42), 1659-1666.
\end{abstract}

Kulcsszavak: hősokkfehérje, májmútét, májkárosodás, ischaemia-reperfúzió

\section{The influence of heat shock proteins on hepatic ischaemia reperfusion injury}

Hepatic ischemia-reperfusion injury as a result of inflow obstruction is a major cause of morbidity and mortality associated with liver pathologies and surgery. Heat shock proteins, a family of stress-inducible proteins involved in maintaining cell homeostasis and regulating the immune system play a major role in liver regeneration. They serve as crucial indicators of ischemia-reperfusion injury in human liver and influence liver function and recovery. The primary objectives of this article are to review the potential role of heat shock proteins as a diagnostic marker for liver diseases and therapeutic target in critical illness. The review will start by focusing on the essentials of heat shock proteins as an endogenous system as it relates to hepatic injury. It will elucidate the influence of heat shock protein-70 on hepatic diseases and ischemia-reperfusion. It will then look at their potential diagnostic role and finally highlights its activities as a possible therapeutic tool.

Keywords: heat-shock protein, liver surgery, hepatic injury, ischemia-reperfusion

Rostás, A., Sabry, A., Ghosh, S. [The influence of heat shock proteins on hepatic ischaemia reperfusion injury]. Orv. Hetil., 2016, 157(42), 1659-1666.

(Beérkezett: 2016. május 29.; elfogadva: 2016. augusztus 9.)

\section{Rövidítések}

ADP = adenozin-difoszfát; ALT = alanin-aminotranszferáz; ARF $=$ akut vesekárosodás; AST $=$ aszpartát-aminotranszferáz; ATP $=$ adenozin-trifoszfát $;$ DNS $=$ dezoxiribonukleinsav; $\mathrm{ER}=$ endoplazmatikus reticulum; ET = endothelin; HS = hősokk; HSF = hősokkfaktor; HSP = hősokkfehérje; IL = interleukin;
$\mathrm{I} / \mathrm{R}=$ ischaemia-reperfúzió; $\mathrm{kDa}=$ kilodalton; $\mathrm{LDH}=$ laktátdehidrogenáz; $M E S$ = mérsékelt elektromos stimuláció; mRNS $=$ messenger ribonukleinsav; $\mathrm{NF}-\kappa \mathrm{B}=$ nukleáris faktor kappa- $\mathrm{B}$; PARP = poli-ADP-ribóz-foszforiláz; ROS = reaktívoxigén-eredetú szabad gyök; TNF = tumornekrózis-faktor 
Az 1960-as évek elején Ferruccio Ritossa - Szent-Györgyi Albert Bioenergetika címú könyvének hatására - a paviai genetikai intézetben kidolgozott egy autoradiográfiai módszert, amellyel a Drosophila melanogaster nyálmirigyének sejtjeiben termelődő nukleinsavat tanulmányozta. Akkoriban a génexpressziót csak a Drosophilához hasonló szervezetekben tudták tanulmányozni és a génaktivitást mutató kromoszomálispuff-képződést fénymikroszkóppal vizsgálták. Ez a kis légy segítette hozzá Ritossát egy új, a lárva fejlődésének meghatározott szakaszában teljesen szokatlan kromoszómapuff-mintázat felfedezéséhez, miután véletlenül magasabb hőfokon felejtette az inkubátort. Ezt, a szövetekre véletlenszerüen kifejtett hősokkot a későbbiekben Ritossa sikeresen megismételte, és 1962-ben felfedezte, hogy ez a speciális fehérjecsoport kromoszómaszegmensekben van kódolva és restriktív körülmények között fejeződik ki. Ezt a speciális fehérjecsoportot nevezték el hősokkfehérjéknek (HSP) [1].

\section{Hősokkfehérje-családok}

Az elmúlt 30 évben ennek a családnak számos további tagját fedezték fel, ezeket hívjuk összefoglaló néven HSPs-nek. A HSPs-t behatóan tanulmányozták, különös tekintettel a sejtekben való elhelyezkedésükre, szabályozásukra, valamint funkciójukra [2]. Ezek a fehérjék mind a prokaryota-, mind az eukaryotasejtekben megtalálhatók, ami arra utal, hogy fontos szerepet töltenek be az alapvető sejtfolyamatokban [3]. A HSPs-t eredetileg „hősokk”-nak [4] kitett Drosophila melanogaster lárvákban fedezték fel, és később számos alcsoportjukat azonosították a $70 \mathrm{kDa}$ tartományban [5]. A HSPs többségének molekulasúlya a 15 és 110 kDa közötti tartományban van, csoportosításukat különböző családokba méretük, illetve funkciójuk szerint történik [6]. Jelen vannak a citoszolban, a mitokondriumokban, az endoplazmatikus reticulumban és a sejtmagban, azonban az egyes fehérjék elhelyezkedése eltérő lehet. Emlősökben a 60, 70, 90 és 110 kDa molekulasúlyú fehérjék a legtöbbet tanulmányozottak és a legjobban ismertek. Ezek a HSPs-ek optimális testhőmérsékleten $\left(\sim 37^{\circ} \mathrm{C}\right)$ és stresszhelyzetben (például: hősokk) is kifejeződnek, elhelyezkedésük és funkcionális tulajdonságaik is meghatározottak (1. táblázat). A kis molekulasúlyú fehérjék, amelyeket small HSPs-nek is nevezünk, szövetspecifikus kifejeződést mutatnak, ezek közé tartozik a hem oxigenáz, a Hsp32, a Hsp27, az aB-krisztalli és a HSP20 chaperon.

\section{A chaperon}

A hősokkválasz szerves része egy ősi, sejten belüli védekezési mechanizmusnak, amely több milliárd éven át fennmaradt és jelen van ma is számos szervezetben a baktériumoktól kezdve a gyümölcslegyeken át egészen az emberig. Hogyan nyújt védelmet ez az ôsi mechanizmus a környezeti hatásokkal szemben? A legtöbb hő-
1. táblázat | Emlőshősokkfehérje-családok sejten belüli elhelyezkedése és feltételezett funkciója

\begin{tabular}{|c|c|c|}
\hline HSP család & $\begin{array}{l}\text { Sejten belüli } \\
\text { elhelyezkedés }\end{array}$ & Feltételezett funkció \\
\hline HSP27 (sHSP) & Sejtplazma, sejtmag & $\begin{array}{l}\text { Mikrofilamentum- } \\
\text { stabilizálás, } \\
\text { antiapoptózis }\end{array}$ \\
\hline HSP60 & Mitokondrium & $\begin{array}{l}\text { Fehérjék újratekerése, } \\
\text { denaturált fehérjék } \\
\text { aggregációjának } \\
\text { gátlása, pro- és } \\
\text { antiapoptotikus }\end{array}$ \\
\hline $\begin{array}{l}\text { HSP70 család: } \\
\text { - HSP72 (Hsp70) } \\
\text { - HSP73 (Hsc70) } \\
\text { - HSP75 (mHSP70) } \\
\text { - HSP78 (GRP78) }\end{array}$ & $\begin{array}{l}\text { - Sejtplazma, sejtmag } \\
\text { - Sejtplazma, sejtmag } \\
\text { Mitokondrium } \\
\text { - ER }\end{array}$ & $\begin{array}{l}\text { - Fehérje feltekerése, } \\
\text { sejtvédelem } \\
\text { - Molekuláris } \\
\text { chaperonok } \\
\text { - Sejtvédelem, } \\
\text { molekuláris } \\
\text { chaperonok }\end{array}$ \\
\hline HSP90 & $\begin{array}{l}\text { Sejtplazma, ER, } \\
\text { sejtmag }\end{array}$ & $\begin{array}{l}\text { Szteroidhormon- } \\
\text { receptorok } \\
\text { szabályozása, } \\
\text { fehérjetranszlokáció }\end{array}$ \\
\hline HSP110/104 & Sejtplazma & Fehérje újratekerése \\
\hline
\end{tabular}

sokkfehérje chaperon. A molekuláris chaperonokat leginkább olyan fehérjékként jellemezhetjük, amelyek a sérült fehérjék újratekerését (refolding) irányítják, mégpedig úgy, hogy az egyébként instabil, sérült fehérjét megkötik és stabilizálják. Így a chaperonok a helyes irányba terelik a fehérjéket. A káros aggregálódott fehérjéket a chaperonok széthúzogatják és újrarendezik. Összegyưjtik a sérült fehérjéket úgy, hogy a szignálszekvenciákat felismerve összekapcsolódnak velük és a javíthatatlan fehérjéket az elpusztítás helyére szállítják.

A sérült polipeptidek normális állapotba való újratekeréséhez szükséges szerkezetbeli változásokat a chaperonineknek nevezett fehérjekomplexek segítik. A folyamat során az adenozin-trifoszfát (ATP) enzimatikus hidrolízise megy végbe (1. ábra). A chaperon hozzákötődik a sérült fehérjéhez, majd bezárja azt a két gyưrüjének valamelyik üregébe, ahol a hidrofób környezetben a fehérjék gyors újratekerése lezajlik, majd a fehérje újból szabaddá válik. Ennek során a tekeredő fehérje nem tud más fehérjékkel érintkezni, így az aggregáció nem tud létrejönni. Amennyiben a folyamat sikertelen és a fehérje ismételt újratekerésre szorul, úgy ismét kapcsolódni fog egy chaperoninhoz.

\section{A máj ischaemiás-reperfúziós károsodása}

Az ischaemiás-reperfúziós $(\mathrm{I} / \mathrm{R})$ sérülés a májkárosodás egyik fó oka a májreszekcióval járó mútétek, valamint májtranszplantáció során [7]. Az égéshez és a haemorrhagiás sokkhoz hasonlóan [8] az I/R sérülés összetett patofiziológia, amelynek kialakulásában számos tényező játszik szerepet [9]. Az ischaemiás inzultus a sejten belü- 


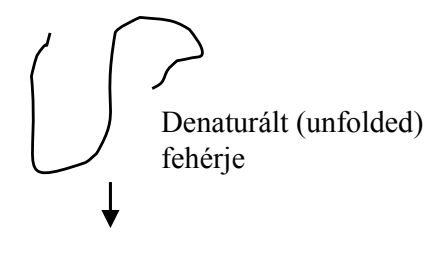

Natív (folded) fehérje
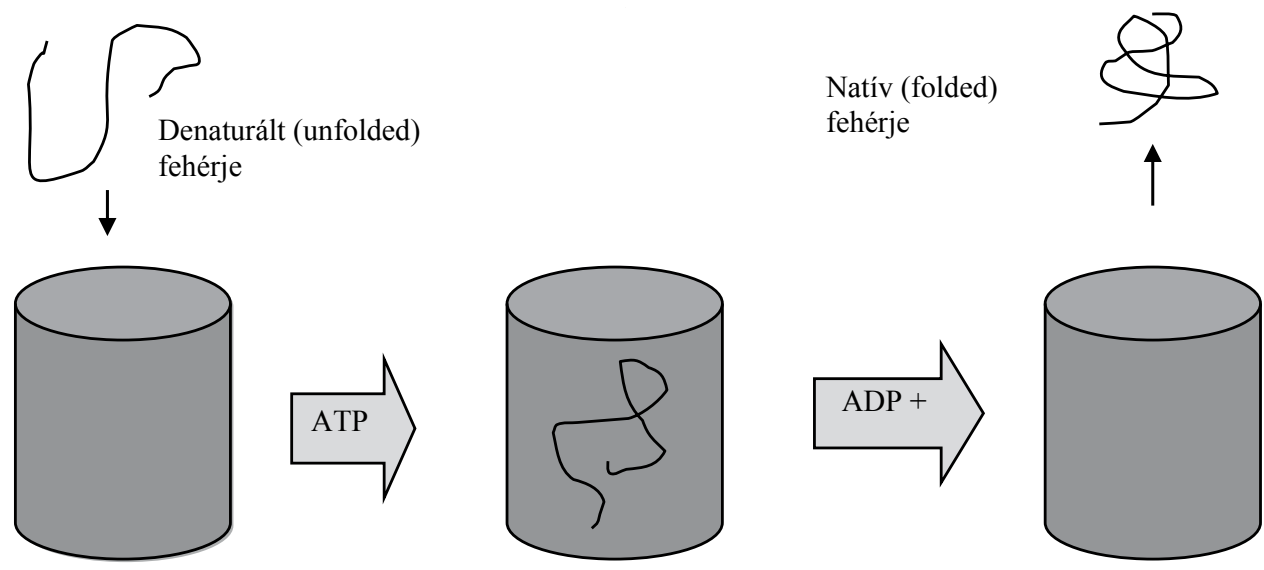

Chaperon

1. ábra

A molekuláris chaperon kapcsolatba kerül a denaturált fehérje alegységeivel, stabilizálja azt és elősegíti a megfelelő újratekerődést. A folyamathoz ATP hidrolízis szükséges

li adenozin-trifoszfát (ATP) szintjének csökkenésével jár, és a következményesen kialakult laktátfelhalmozódás subletalis sejtkárosodáshoz vezet, amelyet a különböző intracelluláris forrásokból, többek között a xantin-oxidáz által indukált reaktívoxigén-eredetû szabadgyökképződés (ROS) is elősegít [10]. Mindezek mellett az olyan proinflammatorikus mediátorok képződése, mint az endothelin (ET) és a tumornekrózis-faktor-alfa (TNF- $\alpha$, valamint a neutrofil akkumuláció is fokozzák a károsodást [11]. A mikrokeringés változása alulperfundált területek kialakulását okozza a májban, fokozva ezzel az ischaemiás károsodás kockázatát [12].

A hepatocyták többféle citoprotektív anyag, mint a glutation, a szuperoxid dizmutáz és a hem-oxigenáz segítségével védik meg a sejt integritását az oxidatív károsodástól [13]. Ezeket a rendszereket, valamint az egyéb citoprotektív fehérjéket, mint például a HSP70-et is alaposan tanulmányozták és tudjuk, hogy ezen fehérjék kifejeződése az ischaemiás-reperfúziós sérülés során a hepatocytákat érő oxidatív károsodás ellensúlyozására jön létre [14].

A hősokkfehérjék (HSPs) fontos szerepet játszanak a sejt homeosztázisának fenntartásában mind a normális sejtnövekedés, mind a káros környezeti hatásokra adott válaszreakció során [15]. A HSPs családjába tartozó fehérjék közül a HSP27 és a HSP70 sejt- és szövetvédő tulajdonságai a legismertebbek a különböző fiziológiai és patológiai ágensek, mint az interleukin-1 (IL-1) [16], a tumornekrózis-faktor- $\alpha$ (TNF- $\alpha)$ [17], valamint az ischaemia-reperfúzió [14] okozta károsodásokkal szemben. A sejt- és állatmodelleket vizsgáló tanulmányok kimutatták, hogy a hősokkfehérjék fehérje- és mRNS-szinten is indukálhatóak a sejtnövekedés serkentésére, valamint a szövetek sérülésekkel szembeni védelmére [18]. Ebből következik, hogy a stresszválasz által fokozott HSPs-kifejeződés a szöveti sérülésre adott védekezési mechanizmus fontos része.

\section{Az endogén rendszer}

\section{HSP70}

\section{Molekuláris háttér}

A HSP70 család a leginkább hőérzékeny és a legősibb a hősokkfehérjék közül. A HSP70 ATP-kötő fehérje és az eukaryotasejtekben előforduló képviselőik 60-80\%-os szerkezeti hasonlóságot mutatnak [19]. A Hsp70 génje 2440 bázispárból áll, ezen belül 212 bázispár leader szekvenciát és 242 bázispár $3^{\prime}$ nem transzlálódó vagy downstream régiót tartalmaz [20]. Legalább két olyan szabályozó elem van az 5 ' régióban, amely a hősokk transzkripciós faktorokra (HSFs) hat. Ezek a HSFs-ek stressz hatására a promóterhez kötődnek és képesek a Hsp70 transzkripcióját indukálni. A hyperthermia mellett számos egyéb tényező képes indukálni a Hsp70 transzkripcióját, mint például: energiahiány, hypoxia, acidózis, ischaemia-reperfúzió, reaktívoxigén-eredetú szabad gyökök (ROS), reaktívnitrogén-eredetű szabad gyökök, mint a nitrogén-monoxid és a vírusfertőzés.

\section{Sejten belüli szerep}

A HSP70-et eredetileg molekuláris chaperonként határozták meg, amely fontos szerepet játszik a transzmitokondriális fehérje szállításában [21]. Mindezen tulajdonságok mellett a HSP70-nek jelentős citoprotektív szerepe van. A HepG2 májsejtekben fokozattan kifejeződő HSP70 - a mitokondriális membránpotenciál stabilizálásával - védelmet nyújt a $\mathrm{H}_{2} \mathrm{O}_{2}$ indukálta sejthalállal szemben [22]. Hasonlóképpen, a geranylacetone által indukált HSP70 megakadályozza a $\mathrm{H}_{2} \mathrm{O}_{2}$ kiváltotta májsejtapoptózist [23]. Számos bizonyíték van arra, hogy a HSP70 gátolja az apoptózis kaszpáz-3 előtti folyamatait, valamint több kísérletben megfigyelték, hogy a HSP70 kötődik az apoptotikusproteáz-aktiváló faktor-1-hez és megakadályozza a prokaszpáz-9 apoptoszómába épülését [24]. A HSFl a nyugalomban lévő sejtek citoplazmá- 
jában monomer formában van jelen. Stresszhatás, mint például trauma/sokk vagy ischaemia/hypoxia esetén a sejten belüli ionkoncentráció megnövekszik és a proteinkináz-C foszforilálja a HSFl-monomereket, amelyek ily módon trimerizálódnak [25]. A HSFl-trimerek ezután a sejtmagba transzlokálódnak, ahol a DNS-hez kötődve a HSP70 transzkripcióját indukálják. A sejten belüli HSP70 közvetlenül hat a nukleáris faktor kappa-B-re $(\mathrm{NF}-\kappa \mathrm{B})$, meggátolva annak aktivációját. Az NF- $\kappa \mathrm{B}$ egy transzkripciós faktor, amelyről úgy gondolják, hogy ischaemiás-reperfúziós májkárosodás során proinflammatorikus és hepatoprotektív szerepe is van [26]. Ezáltal a sejten belüli HSP70 hatása az NF- $\kappa \mathrm{B}$ aktiválódására egy másik fajta védelmi mechanizmust jelenthet az ischaemia-reperfúzió során. Azonban a HSP70 extracelluláris térbe, jelen esetben a szérumba történő felszabadulását is leírták. Az extracelluláris HSP70 proinflammatorikus citokinként funkcionál a toll-like receptor 2 és 4 aktivációján keresztül [27].

\section{HSP72}

A májban normothermiás ischaemia-reperfúziót követően termelődő hősokkfehérje 72 (HSP72) napjainkban az egyik legtöbbet vizsgált, alapvető stresszfehérje. Az intracelluláris HSP72 sejten belüli funkcióinak fontos része a fehérjeaggregáció kiváltotta fehérje-újratekeredés és a chaperoning [28]. Ezen funkciók összessége fokozza a sejtek túlélését a különböző stresszorokkal szemben. Vizsgálatok kimutatták, hogy az intracelluláris HSP72 indukciója monocytákban befolyásolhatja az immunrendszert. A HSP72 gén transzkripciójának indukciója az inflammátoros citokinek transzkripciójának gátlásához vezethet [29]. A fehérje különféle stressz által kiváltott ingerek hatására képződik, és fontos szerepet tulajdonítanak neki a sejt homeosztázisának fenntartásában és ezáltal a betegek túlélési esélyeinek növelésében [30]. Az intracelluláris térben a HPS72 az inflammátoros citokinek negatív szabályozásában játszhat szerepet, megelőzve a túlságosan magas inflammátoroscitokin-szintet a sejten belül, ami a gyulladás során a sejt véletlenszerú károsodásához vagy halálához vezethet [31].

\section{HSP27}

A HSP27 a HSP szupercsalád tagja, amelyek molekulasúlya a 8 és 170 kDa közötti tartományban van. Emberben a HSP27 egyetlen aktív génben van kódolva a 9-es kromoszómán [32]. A HSP27 expressziójának növelése - a sejtvonalak átmeneti vagy végleges transzfekciójával - a sejtek fokozott ellenállóságával jár bizonyos toxinokkal szemben, mint a doxorubicin, daunorubicin, actinomycin D, vincristin, colchicin, arzenit, hidrogénperoxid és tumornekrózis-faktor [33]. Hsp27 hatással van a sejtek túlélésére, legalábbis részben, a chaperonfunkció által, amely stabilizálja a mikrofilamentumok felépülésének dinamikáját, szabályozza az aktin dinami- káját, fokozott kifejeződése megakadályozza a mikrofilamentumok felbomlását és fokozza a mitogén aktiválta aktinpolimerizációt [34]. A fehérje hősokk vagy mitotikus inger hatására foszforilálódik, ami a jelátviteli mechanizmusok szabályozásában betöltött szerepét látszik igazolni. Újabb tanulmányok azt mutatják, hogy több sejtvonal esetében a HSP27-nek a programozott sejthalál szabályozásában is szerepe van [35].

\section{Diagnosztikus szerep}

A HSPs számos májbetegség esetén nagy mennyiségben fejeződnek ki és részt vesznek a sejtek proliferációjában, differenciációjában, inváziójában, metasztázisában, halálában, valamint a sejtek immunrendszer általi felismerésében. Ezen fehérjék némelyikének kifejeződése szintén pozitív hatással van a stressz által érintett sejtekre. Mint tudjuk, az ischaemiás-reperfúziós károsodáshoz hasonló stresszt egyéb hatások is képesek kiváltani a sejtekben, ezáltal lehetőségünk van tanulmányozni e fehérjék kifejeződésének mechanizmusát.

\section{HSP70}

Korai génválasz a máj ischaemiás-reperfúziós károsodására

In vivo modell

Az ischaemiás májsejtek sejtmagja igen aktív és aktivitása a várható tartományon belül igen széles skálán mozog. $\mathrm{Az}$ ischaemiás májsejtek HSP70 mRNS-expresszióját Sprague-Drawley patkányokon tanulmányozták. Ez rávilágított a kifejeződött gén szerepének fontosságára a máj lipopoliszacharidokra és gyulladásra adott válaszában, amelyeket más fehérjék, például: albumin és alfa-l savas glikoprotein kifejeződésének hatásával vetettek össze [36]. Broughan és mtsai I/R során gyors HSP70-mRNSkifejeződést találtak, míg az albumin-mRNS kifejeződése $\mathrm{I} / \mathrm{R}$ alatt nem változott. Ezek alapján megállapíthatjuk, hogy az ischaemiás májsejtek képesek különböző gének expressziójára (például: HSP70), amelyek hatással lehetnek az I/R-re [36].

\section{Klinikai eredmények}

Boeri és mtsai megmagyarázták az I/R hatását a HSP70mRNS kifejeződésére emberi májban [37]. 40 perc meleg ischaemiát követően megfigyelték a HSP70 mRNSének szignifikáns emelkedését, ugyanakkor csökkent transzamináz-expressziót észleltek megnövekedett fibrinogénszintézis mellett. Ezekből arra következtethetünk, hogy a HSP70-mRNS kifejeződése kedvező szerepet játszhat az I/R során, beleértve a csökkent transzamináz-képződést és a fibrinogénszintézis gyors helyreállását [37].

Emberi modellen kapcsolatot fedeztek fel az I/R során észlelhető fokozott HSP70-expresszió és a fibrinogénexpresszió helyreállása, valamint a transzaminázszint csökkenése között, amely a májsejtekre gyakorolt védő- 
szerepet tükrözi. Ezen eredmények alapján feltételezhetjük, hogy a HSP70-nek helye lehet az I/R diagnosztikájában és monitorizálásában.

\section{HSP72}

Schoeniger és mtsai azt találták, hogy a Pringle-manőver által kiváltott elnyújtott ischaemia nem aktiválta a HSP72-gént sertésekben addig, amíg a véráramlás helyre nem állt [38]. Arra a következtetésre jutottak, hogy a HSP72-mRNS transzkripciója nagymértéken függ a szuperoxid anionok felszabadulásától. A szuperoxid anionok részvétele a HSP72-gén aktiválásában felveti a portalis vér visszaáramlásának szerepét, habár a portalis pangás szerepének vizsgálata nem szerepelt a tanulmány célkitüzései között. Azonban amennyiben a reperfúzió nem pangó portalis vérrel történt, azonos időtartamú ischaemiát követően a máj kevesebb HSP72-t termel. Mindez arra utal, hogy a pangó portalis vér kedvezőtlen hatást gyakorol a májfunkcióra ischaemia-reperfúziót követően. Amennyiben a hosszabb inzultus következtében kellöen nagy az ischaemiás sokk, úgy akár a nem pangó vér is okozhat oxidatív stresszt és aktiválhatja a hősokkgéneket. Ha a májparenchyma ischaemiás károsodása nem túl súlyos, akkor a reperfúzió során használt vér tulajdonsága lényegesen befolyásolhatja a kimenetelt. Az előző magállapítások arra utalnak, hogy a portalis pangás a HSP72-terelődés egyik fö stresszfaktora, azonban ez a szerep jelentősen csökken, ha megelőzően már jelentős ischaemia állt fenn. Bár a pangó portalis vér viszszaáramlásának HSP72-termelődést indukáló mechanizmusa nem teljesen tisztázott, nagy valószínúséggel komplex folyamatról van szó, amelyben a máj ischaemiareperfúziójában részt vevő faktorok játszanak szerepet. A portalis pangás során a vékonybelekből felszabaduló szabad gyökök feltehetően szerepet játszanak a reperfúzió során létrejövő májszövet-károsodásban. Ezeket ki tudták védeni úgy, hogy portoszisztémás söntöt hoztak létre és megelőzték a splanchnicus vénás pangást. A HSP72-termelődés további okai közé sorolható az endotoxinok és különböző citokinek transzlokációja a belekből portalis pangás során. Megfigyelték, hogy a 15 percen keresztül fenntartott Pringle-manővert követően jelentősen megemelkedett a portalis vér endotoxinszintje, valamint fokozott bakteriális transzlokációt észleltek a bélből a portalis vérbe [39].

A szérumenzimszintek (mint AST, ALT és LDH), valamint a májszövet ATP-vizsgálata széles körben használt a hepatocellularis károsodás felmérésére, habár nincs szignifikáns eltérés a pangásos és nem pangásos csoportok között. Ennélfogva az ATP-koncentráció nem alkalmas a két csoport differenciálására. Amennyiben a Pringle-manőver nem tartott tovább 15 percnél, úgy a kísérleti állatok májkárosodása reverzibilis volt és egy állat sem pusztult el emiatt. A HSP72-termelődés igazolja, hogy a pangó portalis vér reperfúziója jelentősen nagyobb stresszt okoz, mint a nem pangó véré, így felme- rül, hogy az ismételt vagy hosszabb Pringle-manőver során fellépő kumulatív stressz irreverzibilis májkárosodással jár. Következésképpen a HSP72-termelődés jóval érzékenyebben képes az ischaemia-reperfúzió során jelentkező stressz kimutatására, mint a konvencionális paraméterek. A rövid ideig tartó Pringle-manővert követő HSP72-termelődés a májszövetben a pangó portalis vér ischaemiás szövetekbe történő visszaáramlásával hozható összefüggésbe. A pangó portalis vér reperfúziója ischaemiás szövetekre gyakorolt hatását a HSP72-vel ki lehet mutatni, hagyományos biokémiai paraméterekkel azonban nem. A 2. ábra a HSP72 hasznosságát ábrázolja a máj ischaemiás-reperfúziós károsodás mértékének megállapításában.
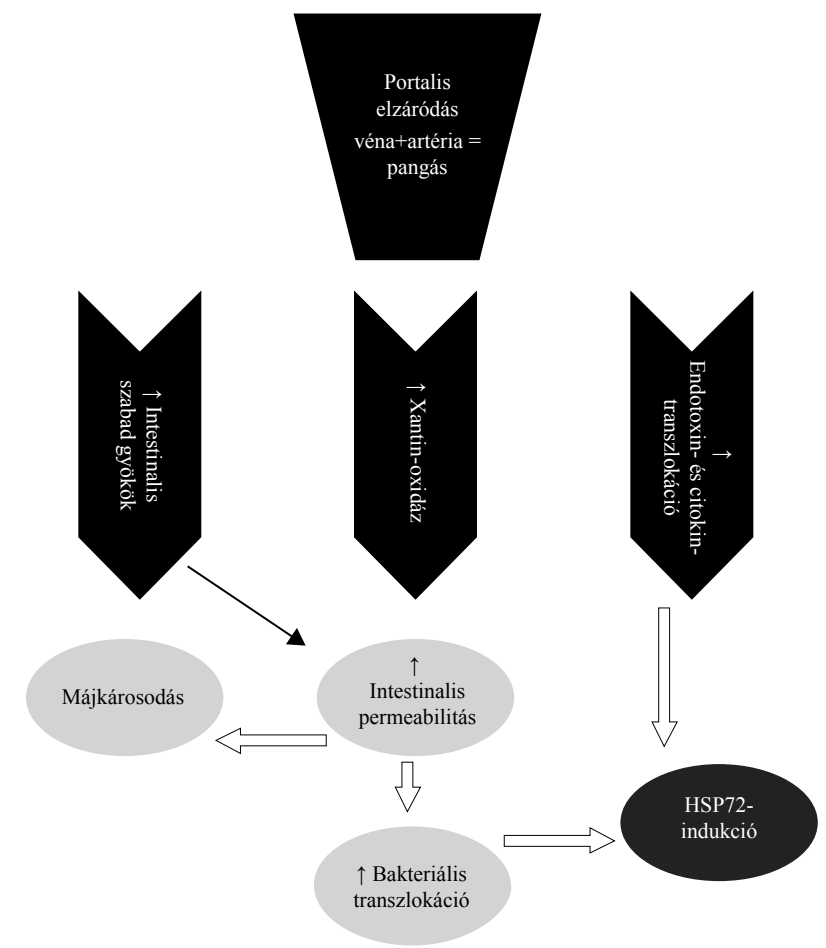

2. ábra A portalis keringés teljes elzáródásának hatását ábrázolja a cito-
kin-, endotoxin- és xantin-oxidáz-termelődésre, amely utóbbi
fokozza a belek permeabilitását és ennek következtében a bakte-
riális transzlokációt, amely a citokinekkel és az endotoxinokkal
együtt a HSP72 kifejeződését fogja indukálni. Látható az össze-
függés az intestinalis szabad gyökök felszaporodása, a fokozott
bélpermeabilitás és a májsejtek károsodása, valamint a májkáro-
sodás és a HSP72-indukció között

\section{Potenciális terápiás lehetőség}

\section{HSP70}

Kuboki és mtsai nátrium-arzenittel stimulálták a HSP70indukciót Male C57BL/6J, wild-type (B6129Fl/Tac háttér) és HSP70 knockout egerekben (Taconic, Germantown, NY) [14]. Az eredmény jelentős májkárosodással és gyulladással szembeni védelem volt, amelyet a HSP70 védőhatásának tulajdonítottak, tekintettel arra, hogy a knockout egerekben hasonló védőhatást nem értek el. Ezt támasztja alá egy korábbi in vitro kísérlet, ahol 
kimutatták, hogy a HSP70 fokozott kifejeződése HepG2-sejtekben jelentősen csökkentette a $\mathrm{H}_{2} \mathrm{O}_{2}$-indukált sejthalált [22].

Érdekes módon az arzenitkezelés során jelentkezô csökkent neutrofil akkumulációt a HSP70 knockout egerekben is megfigyelték. Ezek alapján úgy tűnik, hogy a HSP70 védőhatása független a gyulladásos folyamatoktól, de legalábbis független a máj-neutrofilrecruitmenttől. Nyitott marad a kérdés, hogy milyen módon csökkenti ezt a választ a nátrium-arzenit. Az NF- $\kappa \mathrm{B}$ a proinflammátoros citokinek és citoprotektív fehérjék transzkripcióját szabályozza. Az NF- $\kappa \mathrm{B}$ részvétele számos citokin és adhéziós molekula kifejeződésében sejtkárosodás és stressz során alátámasztja annak szerepét, mint evolúciósan fennmaradt koordináló elem a szervezet válaszreakcióiban. Az NF- $\kappa \mathrm{B}$ antiapoptotikus fehérjeként is funkcionál, amely kihangsúlyozza a sejthalál elleni védelemben betöltött szerepét [26]. Az NF- $\kappa \mathrm{B}$ szerepe a máj ischaemiás-reperfúziós károsodásában még nem teljesen tisztázott. Az NF- $\kappa \mathrm{B}$ aktiválódása a teljes májban ischaemia-reperfúzió során a kiterjedt májkárosodás jele. Az NF- $\kappa$ B aktivációjának pontos szerepe a májsejtekben $\mathrm{I} / \mathrm{R}$ során vitatott és mind a védő, mind pedig a káros hatásra vannak bizonyítékok [40]. Az arzenitkezelést követő fokozott HSFl-aktiváció várhatóan csökkenti mind az NF- $\kappa$ B-aktivációt, mind a proinflammátoros citokin felszabadulását, ahogy azt Kuboki és mtsai megfigyelték [14]. Egy Caco-2 sejtkultúrával (humán intestinalis epithelialis sejtvonal proteaszómainhibitorral) végzett kísérletben Pritts és mtsai azt találták, hogy a proteaszómagátlás hősokkválaszt és IL-6-termelődést vált ki az enterocytákban, valamint, hogy az IL-6 feltehetően hősokkreszponzív gén. Ismert, hogy a HSF1 szabályozza az IL-6-expressziót, és hogy az IL-6 csök- kenti a máj ischaemia-reperfúzió okozta gyulladását [41]. Kuboki és mtsai megállapították, hogy az IL-6 neutralizációja a HSP70 knockout egerekben részlegesen visszafordította az arzenit mediálta neutrofilakkumuláció-csökkenést [14]. Ezek bizonyítják, hogy az ischaemia-reperfúziót követően aktiválódott és az arzenitkezelés által fokozott HSFl-aktiváció a HSP70 és az IL-6 indukcióját eredményezi. Úgy tünik, hogy a HSP70 közvetlen védőhatással van a májsejtekre, és hogy az IL-6 részben a sérült májba történő neutrofilrecruitment gyengítéséért felelős, ahogy azt a 3. ábrán láthatjuk.

Másrészről, a rekombináns HSP70 (rHSP70) alkalmazása nem befolyásolta az ischaemiás-reperfúziós károsodást. Ezek alapján úgy gondoljuk, hogy az intracelluláris HSP70-nek májvédő szerepe van I/R során, míg az extracelluláris HSP70 nincs hatással a sérülésre adott válaszra. Azonban a HSP70 célzott indukciója kiemelkedő terápiás lehetőséget rejt magában a postischaemiás májkárosodás kezelésében.

\section{HSP72}

Oba és mtsai mérsékelt hősokkot (HS) és mérsékelt elektromos stimulációt (MES) alkalmaztak és azt találták, hogy a HS/MES előkezelés csökkentette a máj I/R kiváltotta szérum-AST- és -ALT-felszabadulást, valamint néhány proinflammátoros citokin mRNS-szintjét [42]. A HS + MES prekondicionálás egerekben csökkentette a máj I/R károsodását, feltehetően a HSP72-indukciónak és a csökkent proinflammátoros citokin expressziójának köszönhetően. Az intracelluláris HSP72-nek fontos terápiás szerepe lehet számos neurodegeneratív betegség kezelésében, mint a Parkinson-kór, az Alzheimer-kór, a Huntington-kór és az amyotrophiás lateralsclerosis,

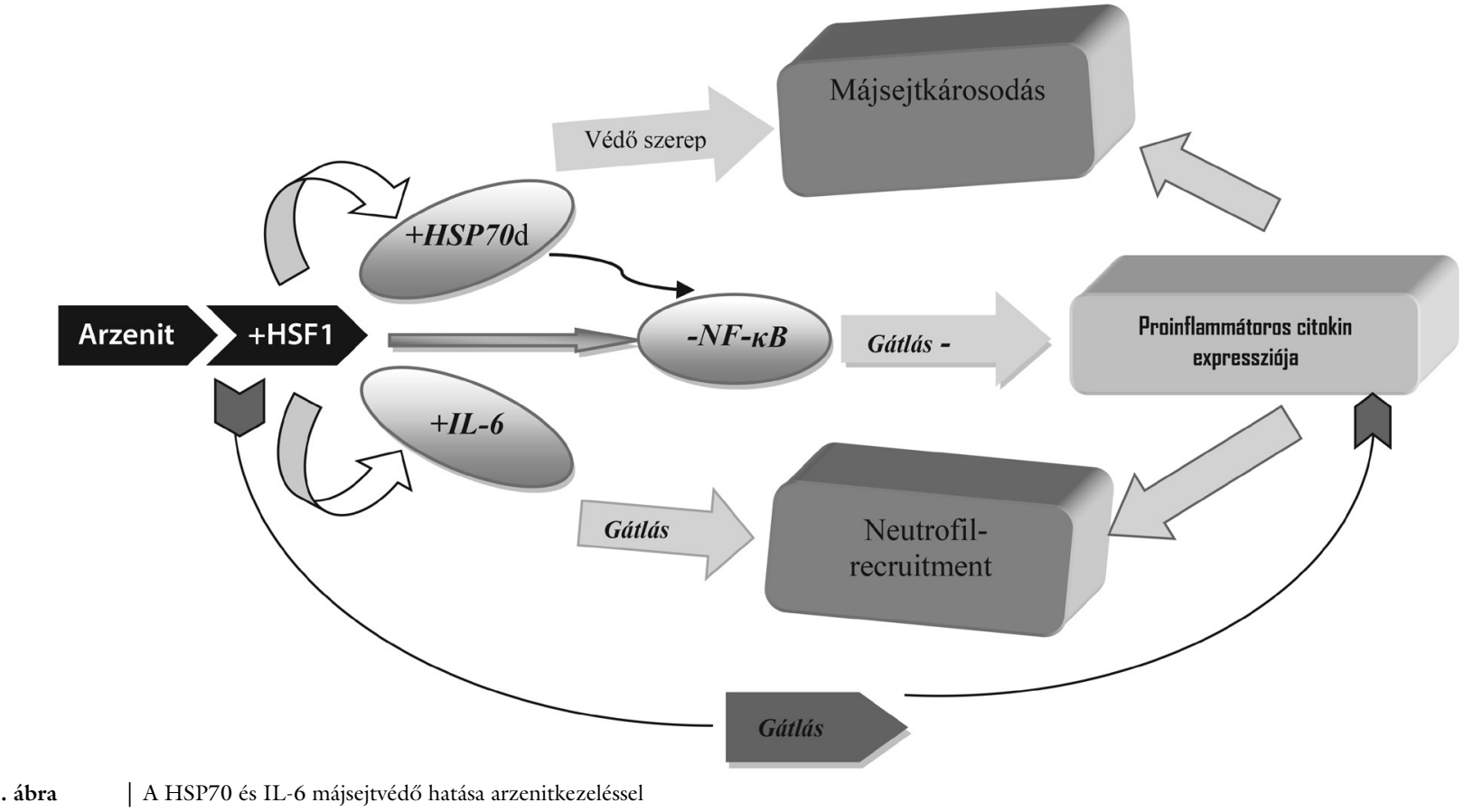


amelyek esetében intracellulárisfehérje-aggregáció (például: $\alpha$-szinuklein, $\beta$-amyloid peptid, szuperoxid dizmutáz) figyelhető meg.

\section{HSP27}

Chen és mtsai kimutatták, hogy rágcsálókban a humán HSP27 fokozott kifejeződése jelentősen csökkenti a májparenchyma-nekrózist I/R-t követően [43]. Az I/R-t követő nekrózisnak kulcsszerepe van a szervelégtelenség kialakulásában, kiemelve a TNF- $\alpha$ szerepét, amely a neutrofilaktivációban és -recruitmentben játszik szerepet. A TNF- $\alpha$-nak és az IL-6-nak kiemelkedő szerepe van a májsejtek ischaemiás prekondicionálásában, amelyről tudott, hogy a máj mikrokeringését védő szerepe van. A nekrózis létrejöhet direkt módon, az ATP hiányában bekövetkező sejthomeosztázis felbomlása által ischaemia alatt és azt követően, vagy indirekt módon, a reperfúzió során, amikor a kontrollálatlanul felszabaduló szabad gyökök és a proinflammátoros hepatopoeticus sejtek okoznak végleges károsodást.

Számos tanulmány bebizonyította, hogy az olyan komplex folyamatok, mint az apoptózis és a nekrózis, morfológiailag különbözőek. A nekrózis a plazmamembrán integritása elvesztésének következménye, de a folyamat részét képezi a citoszolból történő károsító anyagok felszabadulása, valamint a környező szövetek gyulladásos reakciója. Ellenben az apoptózis során a sejt fokozatosan zsugorodik és apoptotikus testekre darabolódik, amelyeket a makrofágok és a környező epithelsejtek gyorsan fagocitálnak. Az akut sérülést tubularis apoptózis követi, amely a tubularis sejtek csökkenéséhez és diszfunkciójához vezet, ami az akut vesekárosodással (ARF) áll kapcsolatban. In vivo ARF-modellekben láthatjuk, hogy vese tubulussejtjeinek apoptózisa két fázisban megy végbe, az első korán, 12-24 órával az akut ischaemiás vagy nephrotoxicus inzultust követően, a második napokkal később, az ARF restitúciós fázisában. A huHSP72 OE egerekben nemcsak a nekrózis csökkent IRI-t követően, hanem az apoptózis is szignifikánsan csökkent a májban (csökkent DNS-létra-képződés és kaszpáz-3-fragmentáció). Az apoptózis fontos szerepet játszik a májelégtelenség kialakulásában I/R-t követően [44]. Az elégtelen foszforilációjú HSP27 expressziója is jelentős rezisztenciát biztosít a proapoptotikus anyagokkal szemben, mint a TNF- $\alpha$, azáltal, hogy a kaszpáz és citokróm c rendszeren keresztül akadályozza meg az apoptózist [45]. További vizsgálatok kimutatták, hogy egerekben a humán HSP27 expressziója védelmet nyújt a májsejtek I/R kiváltotta apoptózisával szemben. A HSP27 globális fokozott kifejeződése nem mindig eredményezi a szervek védelmét az I/R károsodással szemben. Chen és mtsai nemrégiben kimutatták, hogy IRI-t követően a HSP27 fokozott szisztémás expressziója fokozta a vesekárosodást [46]. A májban bekövetkező változások ellentétben állnak azokkal, amelyeket korábban figyeltek meg a vesében, ahol is a huHSP27 OE egerek- ben az I/R fokozza a vesék gyulladását és neutrofil infiltrációját [46]. Ezen eltérés oka nem ismert és további vizsgálatokat igényel. Amennyiben úgy tekintjük, hogy a HSP védőhatású a máj I/R-rel szemben, ami gyakran előfordul májmútét, májátültetés vagy szepszis esetén, így ezeknek az eredményeknek fontos terápiás jelentősége lehet a jövőben.

Anyagi támogatás: A közlemény megírása anyagi támogatásban nem részesült.

Szerzői munkamegosztás: R. A.: Közremúködött a kézirat elkészítésében és a referenciák összeállításában. S. A.: A kézirat megírásában, az ábrák és a táblázat elkészítésében vett részt. G. S.: A koncepció kidolgozása, az absztraktok és a javított verzió elkészítése, valamint hozzájárult a kézirat és a referenciák összeállításához. Minden szerzőnek teljes hozzáférése volt a cikkben közzétett adatokhoz, és felelősséget vállalnak az adatok helyességéért. A cikk végleges változatát valamennyi szerző elolvasta és jóváhagyta.

Érdekeltségek: A szerzőknek nincsenek érdekeltségeik.

\section{Irodalom}

[1] Ritossa, F.: Discovery of the heat shock response. Cell Stress Chaperones, 1996, 1(2), 97-98.

[2] Benjamin, I. J., McMillan, D. R.: Stress (heat shock) proteins. Molecular chaperones in cardiovascular biology and disease. Circ. Res., 1998, 83(2), 117-132.

[3] Morimoto, R. I., Tissieres, A., Georgopoulos, C.: Progress and perspectives on the biology of heat shock proteins and molecular chaperones. In: The biology of heat shock proteins and molecular chaperones. Cold Spring Harbor Laboratory Press, 1994.

[4] Ritossa, F.: A new puffing pattern induced by temperature shock and DNP in Drosophila. Experientia, 1962, 18(12), 571-573.

[5] Stricker, E. M., Hainsworth, F. R.: Evaporative cooling in the rat: effects of dehydration. Can. J. Physiol. Pharmacol., 1970, 48(1), 18-27.

[6] Hightower, L. E., Hendershot, L. M.: Molecular chaperones and the heat shock response at Cold Spring Harbor. Cell Stress Chaperones, 1997, 2(1), 1-11.

[7] Clavien, P. A., Harvey, P. R., Strasberg, S. M.: Preservation and reperfusion injuries in liver allografts. An overview and synthesis of current studies. Transplantation, 1992, 53(5), 957-978.

[8] Tadros, T., Traber, D. L., Herndon, D. N.: Hepatic blood flow and oxygen consumption after burn and sepsis. J. Trauma, 2000, 49(1), 101-108.

[9] Peitzman, A. B., Billiar, T. R., Harbrecht, B. G., et al.: Hemorrhagic shock. Curr. Probl. Surg., 1995, 32(11), 925-1002.

[10] Müller, M. J., Vollmar, B., Friedl, H. P., et al.: Xanthine oxidase and superoxide radicals in portal triad crossclamping-induced microvascular reperfusion injury of the liver. Free Radic. Biol. Med., 1996, 21(2), 189-197.

[11] Jaeschke, H., Farhood, A., Smith, C. W.: Neutrophils contribute to ischemia/reperfusion injury in rat liver in vivo. FASEB J., 1990, 4(15), 3355-3359.

[12] Serracino-Inglott, F., Habib, N. A., Mathie, R. T.: Hepatic ischemia-reperfusion injury. Am. J. Surg., 2001, 181(2), 160-166. 
[13] Glantzounis, G. K., Yang, W., Koti, R. S., et al.: The role of thiols in liver ischemia-reperfusion injury. Curr. Pharm. Des., 2006 12(23), 2891-2901.

[14] Kuboki, S., Schuster, R., Blanchard, J., et al.: Role of heat shock protein 70 in hepatic ischemia-reperfusion injury in mice. Am. J. Physiol. Gastrointest. Liver Physiol., 2007, 292(4), G1141G1149.

[15] Hartl, F. U.: Molecular chaperones in cellular protein folding. Nature, 1996, 381(6583), 571- 579.

[16] Reilly, N., Poylin, V., Menconi, M., et al.: Probiotics potentiate IL-6 production in IL-1 beta-treated Caco- 2 cells through a heat shock-dependent mechanism. Am. J. Physiol. Regul. Integr. Comp. Physiol. Rev., 2007, 293(3), R1169-R1179.

[17] Carlson, R. M., Vavricka, S. R., Eloranta, J. J., et al.: fMLP in duces Hsp27 expression, attenuates NF-kappaB activation, and confers intestinal epithelial cell protection. Am. J. Physiol. Gastrointest. Liver Physiol., 2007, 292(4), G1070-G1078.

[18] Kültz, D.: Molecular and evolutionary basis of the cellular stress response. Annu. Rev. Physiol., 2005, 67, 225-257.

[19] Bardwell, J. C., Craig, E. A.: Major heat shock gene of Drosophila and the Escherichia coli heat-inducible dnaK gene are homologous. Proc. Natl. Acad. Sci. U.S.A., 1984, 81, 848-852.

[20] Wu, B. J., Kingston, R. E., Morimoto, R. I.: Human HSP70 promoter contains at least two distinct regulatory domains. Proc. Natl. Acad. Sci. U.S.A., 1986, 83(3), 629-633.

[21] Kiang, J. G., Tsokos, G. C.: Heat shock protein $70 \mathrm{kDa}$ molecular biology, biochemistry, and physiology. Pharmacol. Ther., 1998 , $80(2), 183-201$.

[22] Hosoi, N., Itoh, H., Koyama, K., et al.: Overexpression of the heat shock protein 70 confers protection against oxidative injury in HEPG2 cells. Transplant. Proc., 2002, 34(7), 2647-2649.

[23] Ikeyama, S., Kusumoto, K., Miyake, H., et al.: A non-toxic heat shock protein 70 inducer, geranylgeranylacetone, suppresses apoptosis of cultured rat hepatocytes caused by hydrogen peroxide and ethanol. J. Hepatol., 2001, 35(1), 53-61.

[24] Beere, H. M., Wolf, B. B., Cain, K., et al.: Heat-shock protein 70 inhibits apoptosis by preventing recruitment of procaspase- 9 to the Apaf- 1 apoptosome. Nat. Cell Biol., 2000, 2(8), 469-475.

[25] Ding, X. Z., Smallridge, R. C., Galloway, R. J., et al.: Increases in HSFl translocation and synthesis in human epidermoid A-431 cells: role of protein kinase $\mathrm{C}$ and $[\mathrm{Ca} 2+]$ i. J. Investig. Med., 1996, 44(4), 144-153.

[26] Ghosh, S., May, M. J., Kopp, E. B.: NF-kappa B and Rel proteins: evolutionarily conserved mediators of immune responses. Annu. Rev. Immunol., 1998, 16, 225-260.

[27] Asea, A., Rebli, M., Kabingu, E., et al.: Novel signal transduction pathway utilized by extracellular HSP70: role of toll-like receptor (TLR) 2 and TLR4. J. Biol. Chem., 2002, 277(17), 1502815034 .

[28] Kimoto, S., Yamamoto, Y., Yamagami, K., et al.: The augmentative effect of repeated heat shock preconditioning on the production of heat shock protein 72 and on ischemic tolerance in rat liver tissue. Int. J. Hyperthermia, 2000, 16(3), 247-261

[29] Housby, J. N., Cabill, C. M., Chu, B., et al.: Non-steroidal antiinflammatory drugs inhibit the expression of cytokines and induce HSP70 in human monocytes. Cytokine, 1999, 11(5), 347358

[30] Shimabukuro, T., Yamamoto, Y., Kume, M., et al.: Induction of heat shock response: effect on the rat liver with carbon tetrachloride-induced fibrosis from ischemia-reperfusion injury. World J. Surg., 1998, 22(5), 464-468

[31] Welch, W. J.: Mammalian stress response: cell physiology, structure/function of stress proteins, and implications for medicine and disease. Physiol. Rev., 1992, 72(4), 1063-1081.
[32] Ciocca, D. R., Oesterreich, S., Chamness, G. C., et al.: Biological and clinical implications of heat shock protein 27000 (Hsp 27): a review. J. Natl. Cancer Inst., 1993, 85(19), 1558-1570.

[33] Landry, J., Chrétien, P., Lambert, J., et al.: Heat shock resistance conferred by expression of the human HSP27 gene in rodent cells. J. Cell Biol., 1989, 109(1), 7-15.

[34] Lavoie, J. N., Lambert, H., Hickey, E., et al.: Modulation of cellular thermoresistance and actin filament stability accompanies phosphorylation-induced changes in the oligomeric structure of heat shock protein 27. Mol. Cell. Biol., 1995, 15(1), 505-516.

[35] Arrigo, A. P.: Small stress proteins: chaperones that act as regulators of intracellular redox state and programmed cell death. Biol. Chem., 1998, 379(1), 19-26.

[36] Broughan, T. A., Jin, G. F., Papaconstantinou, J.: Early gene response to hepatic ischemia/reperfusion. J. Surg. Res., 1996, 63(1), 98-104.

[37] Boeri, D., Dondero, F., Storace, D., et al.: Heat-shock protein 70 favours human liver recovery from ischaemia-reperfusion. Eur. J. Clin. Invest., 2003, 33(6), 500-504.

[38] Schoeniger, L. O., Andreoni, K. A., Ott, G. R., et al.: Induction of heat-shock gene expression in postischemic pig liver depends on superoxide generation. Gastroenterology, 1994, 106(1), 177184.

[39] Liu, L., Jeppsson, B., Bengmark, S.: Bacterial translocation into portal blood from the gut during portal triad occlusion. Dig. Surg., 1992, 9(2), 95-101.

[40] Kuboki, S., Okaya, T., Schuster, R., et al.: Hepatocyte NF-кB activation is hepatoprotective during ischemia/reperfusion injury and is augmented by ischemic hypothermia. Am. J. Physiol. Gastrointest. Liver Physiol., 2007, 292(1), G201-G207.

[41] Pritts, T. A., Hungness, E. S., Hershko, D. D., et al.: Proteasome inhibitors induce heat shock response and increase IL- 6 expression in human intestinal epithelial cells. Am. J. Physiol. Regul. Integr. Comp. Physiol., 2002, 282(4), R1016-R1026.

[42] Oba, M., Suico, M. A., Morino, S., et al.: Modified mild heat shock modality attenuates hepatic ischemia/reperfusion injury. J. Surg. Res., 2010, 162(2), 213-220.

[43] Chen, S. W., Park, S. W., Kim, M., et al.: Human heat shock protein 27 overexpressing mice are protected against hepatic ischemia and reperfusion injury. Transplantation, 2009, 87(10), 1478-1487.

[44] Ghosh, S., Baumann, J., Falusi, B., et al.: Hemodynamic effects of $\mathrm{N}$-acetylcystein and ischemic preconditioning in a liver ischemiareperfusion model. [Az N-acetilcisztein hemodinamikai hatása és ischaemiás prekondicionálás máj ischaemia-reperfúzió modellen.] Orv. Hetil., 2008, 149(47), 2245-2249. [Hungarian]

[45] Concannon, C. G., Gorman, A. M., Samali, A.: On the role of Hsp27 in regulating apoptosis. Apoptosis, 2003, 8(1), 61-70.

[46] Chen, S. W., Kim, M., Kim, M.: Mice that overexpress human heat shock protein 27 have increased renal injury following ischemia reperfusion. Kidney Int., 2009, 75(5), 499-510.

(Subhamay Ghosh, M.D., PhD, Consultant Anaesthetist, Member of Research and Development Committee, Hywel Dda University Health Board, Anaesthetics and Pain Management, Glangwili General Hospital, Dolgwili Road, Carmarthen, SA3I 2AF, U.K. e-mail: ghoshdr@gmail.com) 